\title{
Między fantazją a rzeczywistością. Rzecz o strategiach konstruowania edukacyjno-zawodowej przyszłości
}

\begin{abstract}
Streszczenie
Celem artykułu jest zaprezentowanie wyników badawczych dociekań prowadzonych wśród uczniów ostatnich klas szkół podstawowych, stojących wobec wyboru ścieżki edukacyjno-zawodowej - koncentrując się na odpowiedziach na pytania o to, jakie strategie/style planowania przyszłości obierają uczniowie, skupiając się na opisie strategii konstruowania przyszłości stosowanych przez młodzież, wskazując także na zmienne różnicujące obierane strategie. Inspiracją stały sie badania C. Timoszyk-Tomczak (2003), która analizując strategie i style konstruowania przyszłości (s. realistyczna, autorytetu, przymusu, życzeniowa, oczekiwania i carpe diem), zwróciła uwagę na ich różnorodność, będącą konsekwencją miedzy innymi kontekstu, w którym żyje „konstruktor”, mnogości jego doświadczeń i wachlarza możliwości do wyboru, rozpoznano deklaracje młodzieży szkół podstawowych w kwestii obieranych przez nią strategii planowania. Respondentów poproszono o wybranie dwóch deskrypcji najlepiej eksplikujących ich sytuację, zakładając, iż młodzież korzysta z kilku strategii jednocześnie, tworząc ich hybrydy - wobec różnorodnych kontekstów funkcjonowania i rozważanych obszarów. Respondenci określili, iż najlepiej opisującą ich aktualny sposób działania jest strategia realistyczna (59,50\%) oraz strategia autorytetu (46,40\%). Opowiedzenie się przez badanych za którymś z wa-
\end{abstract}

1 Joanna Wanda Kozielska, Wydział Studiów Edukacyjnych, Uniwersytet im. Adama Mickiewicza w Poznaniu, Polska, e-mail: askowr@amu.edu.pl, ORCID ID: https://orcid.org/0000-00022319-9644. 
riantów dostarczyło informacji o preferowanym stylu działania w zakresie projektowania przyszłości i podejmowania znaczących życiowo decyzji, uwzględniając także ich temporyzacyjny aspekt.

\title{
Słowa kluczowe:
}

młodzież, strategie konstruowania planów, wybory edukacyjno-zawodowe, poradnictwo zawodowe, szkoła podstawowa, szkoła ponadpodstawowa

\begin{abstract}
Drawing inspiration from the research of C. Timoszyk-Tomczak (2003), who, analyzing the strategies and styles of constructing the future (realistic, authority, coercion, wishful thinking, expectations and carpe diem), drew attention to their diversity, which is a consequence of, among others, the context for whom the „constructor” lives, the multitude of his experiences and the range of possibilities to choose from, it was decided to examine the declarations of primary school youth on the planning strategies they choose. Students were asked to choose 2 descriptions that best explicate their current situation, assuming that young people can use several strategies simultaneously, creating their hybrids to various contexts of youthful functioning and areas under consideration. Students opting for any of the options provided information about their preferred style of action in terms of designing the future and making significant life decisions, also taking into account their temporative aspect. Which of the strategies for constructing the future they lean towards in their career endeavors - may be a determinant of their sense of professional satisfaction and a sense of achieving professional success versus its lack.
\end{abstract}

\section{Keywords:}

youth, career counseling, strategies for constructing plans, educational and career choices, primary school, secondary school

\section{WPROWADZENIE}

Celem artykułu jest zaprezentowanie wyników badawczych dociekań, prowadzonych wśród uczniów ostatnich klas szkół podstawowych, stojących wobec wyboru edukacyjno-zawodowej ścieżki. Młodzi, których wybory edukacyjne i strategie w ich obszarze uczyniono podstawowym tematem prezentowanego tekstu, to drugi rocznik uczniów, który nie kontynuował nauki w gimnazjum. To wyjątkowa grupa, która ponownie realizuje nagle przywrócone role uczniów klas 
VII i VIII. To młodzi ludzie, którzy przed wyborem szkoły ponadpodstawowej stoją po raz pierwszy, zostali bowiem pozbawieni możliwości wyboru szkoły gimnazjalnej. Jednocześnie o rok wcześniej postawiono ich wobec konieczności podejmowania decyzji - istotnej, bo już znacząco profilującej (kształcenie ogólne versus branżowe) ich edukacyjne losy. $Z$ tej perspektywy przedstawione wyniki są bardzo ważne, zarówno dla innych badaczy, jak i dla praktyków - wychowawców klas i doradców zawodowych pracujących z młodzieżą w tym wieku. Mimo iż problematyka karier czy wyborów edukacyjno-zawodowych jest częstym tematem badań pedagogów (i pedagogów pracy), to z uwagi na zmiany w strukturze szkolnictwa brakuje obecne aktualnych doniesień na temat wyborów uczniów szkół podstawowych (także w kontekście (nowo)powstałego szkolnictwa branżowego). Celem projektu², którego jeden z modułów zostanie zrelacjonowany w niniejszym tekście, było: dokonanie charakterystyki aspiracji i planów oraz czynionych przez młodzież wyborów edukacyjno-zawodowych; przedstawienie opinii młodzieży na temat kategorii „,sukces” (w tym sukces zawodowy) wraz z opiniami na temat jego uwarunkowań; dokonanie charakterystyki asocjacji towarzyszących młodzieży na temat ścieżek kształcenia umożliwiających vs uniemożliwiających osiągniecie sukcesu zawodowego (technika, szkoły branżowe vs licea ogólnokształcące) i zawodów prestiżowych vs nieprestiżowych oraz dokonanie charakterystyki (będącej konsekwencją poczynionej przez uczniów ewaluacji) procesu doradztwa zawodowego oraz opis jego pożądanego przez uczniów kształtu. W tak zaprojektowanym, kilkumodułowym projekcie jednym z problemów badawczych uczyniono pytanie o strukturę wyborów edukacyjno-zawodowych, aspiracji w tym obszarze i planów edukacyjno-zawodowych młodzieży-uczniów szkół podstawowych. W tym module problemy skonstruowano między innymi wokół następujących pytań: Czy i w jakim typie szkoły młodzież zamierza kontynuować naukę? Na jakim etapie rozwoju młodzież podejmuje decyzje edukacyjno-zawodowe? Czym warunkowane są wybory edukacyjno-zawodowe uczniów? Jakimi cechami demograficzno-społecznymi (płeć, miejsce zamieszkania, wykształcenie rodziców, aktywność vs brak aktywności zawodowej rodziców; status materialny rodziny, osiągniecia edukacyjne) charakteryzuje się sylwetka ucznia szkoły podstawowej zainteresowanego vs niezainteresowanego kształceniem w zawodzie? Jak młodzież ocenia swoje szanse na dostanie się do wybranej szkoły ponadpodstawowej? Jakie oczekiwania względem wybranej szkoły średniej prezentują uczniowie szkół pod-

2 Szerszy kontekst badania opisano w monografii pod tytułem: Uczniowie szkół podstawowych i kształcących w zawodzie wobec swojej przyszłości edukacyjno-zawodowej, będącej w trakcie procesu wydawniczego (Wydawnictwo Naukowe UAM). 
stawowych? Jakie znaczenie uczniowie przypisują kategorii „praca” oraz „dobra praca/dobry zawód”?

W niniejszym tekście skoncentrowano się zaś na odpowiedziach na pytania o to, jakie strategie/style planowania przyszłości obierają uczniowie, skupiając się na opisie strategii konstruowania przyszłości stosowanych przez młodzież, wskazując także na zmienne różnicujące obierane strategie. Inspirację do podjęcia weryfikacji w tym zakresie stanowiły badania C. Timoszyk-Tomczak (2003), która wymienia kilka strategii konstruowania planów, definiując je, jako „zbiory reguł (sposobów), za pomocą których jednostka tworzy scenariusz swojego dalszego życia, a więc selekcjonuje informacje, przetwarza je i dokonuje wyborów. Tworzy więc program koordynujący kształtowanie własnych celów i planowanie sposobów ich osiągnięcia” (Timoszyk-Tomczak, 2003, s. 43). Autorka podkreśla, że istotą strategii konstruowania przyszłości jest program umysłowy będący podstawą elastyczności zachowania i je koordynujący. Jak pokazują badania, czynnikami regulującymi perspektywę czasową, jej strukturę, treść i rozległość są: płeć, środowisko społeczne, cykl kształcenia. Wydłużenie czasu i wzrost poziomu edukacji sprzyja rozwojowi realizmu i struktury perspektywy czasowej (Liberska, 2004). Timoszyk-Tomczak, analizując strategie konstruowania przyszłości, zwraca uwagę na ich zróżnicowanie, wynikające m.in. z różnych doświadczeń, możliwości, samodzielności młodych ludzi. W konsekwencji autorka wyróżnia sześć typów strategii przyszłościowych: realistyczną, autorytetu, przymusu, życzeniową, oczekiwania, carpe diem.

Strategia realistyczna polega na obserwacji innych ludzi i samego siebie w celu efektywnego działania we własnym środowisku w różnych dziedzinach życia. Wiąże się z nią umiejętność spostrzegania aktualnej rzeczywistości oraz tworzenie adekwatnych modeli przyszłego świata; wymaga rozważenia własnych pomysłów i alternatyw generowanych przez środowisko.

Strategia autorytetu uwzględnia wykorzystanie rad i wskazówek osób uznawanych za bardziej doświadczone, kompetentne. Preferujący tę strategię mają skłonność do kierowania się poradami osób znaczących, nie dążąc do autonomii w procesie podejmowania decyzji i kształtowania swojej przyszłości.

Strategia przymusu prowadzi do uzależnienia się od rodziców, nauczycieli lub innych czynników zewnętrznych. Osoby stosujące tę strategię kierują się głównie standardami narzuconymi z zewnątrz, co daje im poczucie zwolnienia z odpowiedzialności za podejmowane decyzje. Strategia życzeniowa opiera się na fantazjowaniu na temat własnej przyszłości, lecz bez planowania i określania sposobów realizacji zamierzeń, co nie daje szans na osiągnięcie celu.

Strategia oczekiwania oparta jest na biernym oczekiwaniu na wydarzenia życiowe. Jednostka nie formułuje celów życiowych ani sposobów ich realizacji, 
gdyż uznaje, że przyszłe wydarzenia zależą od pozaosobowych sił związanych z wyznawaną filozofią, ideologią czy religią. Osoby stosujące strategię carpe diem czerpią przyjemność z dnia codziennego, nie planują niczego. U nastolatków dążenie do wartości hedonistycznych nie oznacza braku planowania przyszłości, lecz może być skutkiem życia według norm i wskazówek narzuconych z zewnątrz i braku posiadania alternatywy w momencie wyczerpania się źródeł planów. Do zahamowania procesu konstruowania przyszłości może dojść również w sytuacji przeciążenia informacjami lub dużego oporu przed zmianą, wywołanego np. poglądami, konserwatyzmem, utratą przywilejów (Timoszyk-Tomczak, 2003). Timoszyk-Tomczak (2003) podkreśla, że najkorzystniejszą strategią jest poszukiwanie i wykorzystywanie działań odpowiednich dla sytuacji, w jakiej funkcjonuje i rozwija się jednostka.

Autorkę niniejszego tekstu zainteresowało, które strategie wybiera młodzież szkół podstawowych, snując plany dotyczące edukacyjno-zawodowej przyszłości i podejmując w tym obszarze swoje pierwsze decyzje oraz jakie są zróżnicowania w tym obszarze. Co zdaje się niezwykle interesujące i stanowić może wskazówkę do działań z zakresu doradztwa zawodowego organizowanego w szkołach.

W polskim systemie edukacji ostatni bowiem rok nauki w szkole podstawowej to czas dokonywania wyborów wpływających na przyszłe możliwości zdobycia wykształcenia i zawodu. Po ukończeniu szkoły podstawowej uczeń może kontynuować edukację w szkole branżowej I stopnia³ (do 2017 roku w zasadniczej szkole zawodowej), technikum ${ }^{4}$ lub liceum ogólnokształcącym ${ }^{5}$, co oznacza, że w wieku 15 lat powinien umieć określić swoje zainteresowania, predyspozycje, a także kierunek preferowanego rozwoju edukacyjnego, a w konsekwencji zawodowego. I choć wybory te nie stanowią deterministycznej wizji przyszłego życia - nieustająca kreacja zawodowego oblicza, wobec implementowanej dziś koncepcji lifelong learningu (inwestowania we własny rozwój oraz elastycznego reagowania na zmiany uwarunkowań wyznaczających obrane zawodowe drogi) staje się faktem, to jest to pierwsze z wydarzeń przełomowych dokonywane w czasie tranzycji ze szkoły podstawowej do średniej. Dla młodego człowieka jest to niezwykle trudne - nauka w ostatniej klasie szkoły podstawowej zbiega się bowiem z czasem, w którym następuje intensywny rozwój fizyczny, emocjonalny i poznawczy. To, co młodzież przeżywa, wywołuje często napięcie i poczucie niepewności. Ten okres

${ }^{3}$ Po jej ukończeniu zyskując zasadnicze wykształcanie branżowe, które może uzupełnić w szkole branżowej II stopnia i zdobyć wykształcenie średnie branżowe.

${ }^{4}$ Po jej ukończeniu zdobywając wykształcenie średnie zawodowe.

5 Stając się absolwentem legitymującym się wykształceniem średnim ogólnym. 
rozwoju przynosi także zaburzenie pewniej stabilności i stałości, co odczuwane jest jako zagubienie, osamotnienie czy wręcz niepowodzenia.

To, ku jakiej strategii konstruowania przyszłości skłaniać się będą w swoich przedsięwzięciach podejmowanych na rzecz kariery - może stanowić wyznacznik poczucia ich zawodowej satysfakcji oraz poczucia osiągnięcia sukcesu zawodowego versus jego braku.

\section{MATERIAtY I METODY}

Celem uzyskania odpowiedzi na wskazane wcześniej, wybrane problemy badawcze zastosowano metodę sondażu diagnostycznego. W ramach poczynionego wyboru metody badań dokonano wyboru techniki badawczej. Techniką, która wpisuje się w metodę badań sondażowych, jest ankietowanie, do którego się odwołano, a posłużyło temu narzędzie badawcze, którym uczyniono kwestionariusz ankiety. Ankieta wykorzystana w badaniu składała się z krótkiej metryczki oraz szeregu pytań, niektóre z nich to pytania rozstrzygnięcia, inne natomiast zostały wyposażone w kafeterie zamknięte, półotwarte oraz koniunktywne. Kontekstowo wykorzystano także pytania otwarte.

Zaprezentowane w kolejnej części artykułu badania przeprowadzono w roku szkolnym 2019/2020 w jednym w wielkopolskich powiatów - powiecie gnieźnieńskim, ze szczególnym uwzględnieniem miasta Gniezna, miasta średniej wielkości ${ }^{6}$ (do 100 tysięcy mieszkańców). W przeprowadzonym procesie badawczym, wpisującym się w paradygmat badań ilościowych, wykorzystano łączony schemat doboru próby - schemat celowo-losowy, określając najpierw warstwy próby, stanowione przez celowo wybrane rodzaje szkół, którymi uczyniono szkoły podstawowe, jak

${ }^{6}$ Relacjonowane badania przeprowadzono w Gnieźnie i miastach powiatu gnieźnieńskiego, stanowiącego zachodnią część województwa wielkopolskiego (liczba ludności powiatu wynosi 145085. W skład powiatu wchodzą: gminy miejskie: Gniezno; gminy miejsko-wiejskie: Czerniejewo, Kłecko, Trzemeszno, Witkowo; gminy wiejskie: Gniezno, Kiszkowo, Łubowo, Mieleszyn, Niechanowo; miasta: Gniezno, Czerniejewo, Kłecko, Trzemeszno, Witkowo. Powiaty sąsiednie to powiaty: słupecki, wrzesiński, poznański, wągrowiecki, żniński (kujawsko-pomorskie), mogileński (kujawsko-pomorskie). Stopa bezrobocia rejestrowanego wyniosła w 2015 roku 9,3\% a w roku 2019 3,6\%. Najliczniejszym sektorem zatrudnienia są usługi, dalej rolnictwo, leśnictwo, łowiectwo i rybactwo oraz handel; naprawa pojazdów samochodowych; transport i gospodarka magazynowa; zakwaterowanie i gastronomia; informacja i komunikacja (Wyniki badań bieżących - Baza Demografia - Główny Urząd Statystyczny, www.demografia.stat.gov.pl [dostęp 14.06.2019]; w oparciu o dane GUS 31.12.2014 r. oraz 31.12.2015 r.; Główny Urząd Statystyczny/Obszary tematyczne/ Rynek pracy/Bezrobocie rejestrowane/Bezrobotni zarejestrowani i stopa bezrobocia. Stan w końcu września 2019 r., www.stat.gov.pl [dostęp: 12.09.2019]). 
również miejscowość pod względem liczby mieszkańców (średniej wielkości miasto). W kolejnym etapie losowaniu podlegały grupy uczniów (zespoły klasowe) objęte badaniem. Każdy z uczniów otrzymał ankietę wraz z instrukcją jej wypełnienia. Badania przeprowadzała autorka projektu, w ich przeprowadzeniu pomagali przeszkoleni doradcy zawodowi i nauczyciele realizujący zajęcia z zakresu doradztwa zawodowego, a także szkolni pedagodzy, skupieni wokół gnieźnieńskiego Klubu Doradcy Zawodowego, działającego przy Centrum Kształcenia Zawodowego i Ustawicznego w Gnieźnie. Narzędzie wypełniano w obecności ww. osób z zachowaniem zasady, by nauczyciele wspomagający badaczkę nie przeprowadzali badań w szkole, w której są zatrudnieni.

Celem uchwycenia i rozpoznania związków pomiędzy zmiennymi ${ }^{7}$ i realizacji nakreślonych wcześniej celów badawczych zastosowano wybrane procedury statystyczne, pozwalające na stwierdzenie występowania statystycznej istotności oraz siły zależności pomiędzy analizowanymi czynnikami. Zależności między pytaniami zbadano testem chi-kwadrat Pearsona, a w przypadku, gdy liczności oczekiwane okazały się zbyt małe, użyto testu chi-kwadrat NW (największej wiarygodności). Przy analizie pytań z wielokrotną odpowiedzią w przypadku porównania proporcji odpowiedzi w dwóch grupach zastosowano test istotności różnicy między dwoma wskaźnikami struktury, a w przypadku porównania proporcji odpowiedzi, w co najmniej trzech grupach zastosowano test Fp porównującego k częstości. Za istotną statystycznie przyjęto wartość p<0,05. Ponadto w pytaniach dotyczących prestiżu zawodów i uwarunkowań wyborów edukacyjno-zawodowych przypisano kategoriom odpowiedzi rangi (wartości liczbowe), a same odpowiedzi były traktowane jako zmienne ilościowe. W związku z tym przy obliczeniach zależności dla tych wskazań zastosowany został nieparametryczny test Kruskala-Wallisa do porównania istotności różnic w poziomie ocen respondentów w najmniej trzech grupach. Obliczenia statystyczne przeprowadzono przy użyciu pakietu statystycznego Statistica $10 \mathrm{Pl}$.

Analizie statystycznej i opisowej materiału badawczego zebranego w szkołach podstawowych (klasy VI-VIII) poddano 1099 anonimowych ankiet. Grupa ta

7 Zmiennymi niezależnymi uczyniono: płeć, miejsce zamieszkania, poziom wykształcenia rodziców respondentów, aktywność vs brak aktywności zawodowej rodzica respondenta, deklarowany przez uczniów poziom zaangażowania rodziców w życie edukacyjne respondenta, status materialny rodziny ucznia, poziom osiągnięć edukacyjnych uczniów, poziom zaangażowania ucznia w zajęcia pozaszkole i pozalekcyjne.

Zmienne zależne stanowiły: aspiracje, plany, wybory edukacyjno-zawodowe młodzieży; percepcja sukcesu zawodowego, jego uwarunkowań i samooceny szans na jego osiągnięcie oraz percepcja procesu szkolnego doradztwa zawodowego. 
była niemalże równoliczna, biorąc pod uwagę proporcję kobiet względem mężczyzn - w badaniu udział wzięło 548 uczennic (49,90\%) i 551 uczniów (50,10\%). Ankietowanymi byli uczniowie klas VI, VII i VIII (a zatem osoby w wieku 12-15 lat) tworzący niemalże równoliczne grupy. Zdecydowana większość respondentów ze szkół podstawowych pochodziła z miasta średniej wielkości (od 50 do 150 tys. mieszkańców) stanowiąc $81,00 \%$ próby badawczej. Drugą pod względem wielkości grupę tworzyli uczniowie zamieszkujący obszary wiejskie (16,00\%). Tylko 2,10\% respondentów zamieszkiwało małe miasta (do 50 tys. mieszkańców), a tylko 10 badanych (1,00\%) to mieszkańcy miast powyżej 150 tys. mieszkańców.

Struktura wykształcenia uzyskanego przez rodziców respondentów ze szkół podstawowych jest dość zróżnicowana. Blisko 50,00\% rodziców legitymuje się wyższym wykształceniem (48,40\%). Najwyżej wykształconą, a zarazem najliczniejszą grupę rodziców stanowiły matki - co trzecia z nich zdobyła wyższe wykształcenie. Kolejną pod względem wielkości grupę stanowili ojcowie, także legitymując się wyższym wykształceniem (blisko co piaty ojciec). Struktura wykształcenia rodziców ujawnia swoistą dwubiegunowość - otóż drugą pod względem wielkości grupę stanowili rodzice z wykształceniem zasadniczym zawodowym (30,60\%), z niewielką dominacją mężczyzn w tej kategorii. Blisko dwa razy częściej niż matki średnie szkoły kształcące w zawodzie (technika) kończyli ojcowie respondentów. Niepokojący jest fakt, iż zdecydowana większość respondentów $(75,10 \%)$ nie potrafiła wskazać poziomu wykształcenia swoich rodziców/opiekunów. Podobnych wniosków dostarczyły badania przeprowadzone w latach 2016-2018 (por. Kozielska, 2018a, b), wskazując, iż uczniowie ostatnich klas gimnazjów nie potrafili określić, jaki zawód wykonywali aktualnie rodzice/ opiekunowie ucznia.

Zdecydowana większość rodziców uczniów stanowiących próbę badawczą to osoby aktywne zawodowo (ok 90,00\% ojców i blisko 80,00\% matek uczniów szkół podstawowych i ponadpodstawowych). Brak aktywności zawodowej matek powodowany był sprawowaną przez nie opieką nad osobą/osobami zależnymi (około 15,00\% w przypadku uczniów szkół podstawowych, jak i ponadpodstawowych). Blisko 7,00\% badanych uczniów nie potrafiło określić statusu rodzica/ opiekuna na rynku pracy - uczniowie nie wiedzieli, czy rodzice/opiekunowie pracują, czy też nie. Nieumiejętność wskazania statusu rodzica na rynku pracy była wyższa w kwestii określenia sytuacji zawodowej ojca.

Respondenci wysoko ocenili status materialny swojej rodziny. Blisko 65,00\% ankietowanych określiło go jako wysoki lub bardzo wysoki, wskazując tym samym, iż są z niego zadowoleni, a rodzinę w zasadzie stać na wszystko, czego jej potrzeba. Blisko co trzeci badany uczeń szkoły podstawowej stwierdził, iż status 
materialny ich rodzin należy określić jako przeciętny, wyrażony twierdzeniem: „nie jesteśmy ani biedni, ani specjalnie zamożni”.

Uczniowie szkół podstawowych równie wysoko określili poziom zaangażowania rodziców/opiekunów w proces ich edukacji, wskazując, iż jest on bardzo wysoki lub wysoki. Stwierdzając tym samym, iż rodzicie uczestniczą w spotkaniach z wychowawcą, w razie potrzeby pomagają w lekcjach, organizują zajęcia dodatkowe, w tym korepetycje, oraz często pytają i rozmawiają z dziećmi o szkole, planach na przyszłość, lub zaznaczając, iż rodzice chodzą na wywiadówki, starają się pomagać w lekcjach, organizują korepetycje, a czasami rozmawiają o szkole i planach na przyszłość (łącznie blisko 80,00\%). Co trzeci z ankietowanych określił zaangażowanie rodziców jako przeciętne, określone twierdzeniem: „rodzice średnio interesują się szkołą, chodzą na wywiadówki w razie potrzeby, raczej muszę radzić sobie sam, choć w razie dużych trudności mogę liczyć na ich pomoc”. Uczniowie szkół podstawowych, tworzący próbę badawczą, stanowili grupę, którą z uwagi na wypracowane średnie ocen należy określić jako grupę uczniów bardzo dobrych i dobrych (biorąc pod uwagę średnią ocen wyższą niż 4,01 -stanowili oni blisko 66,00\% wszystkich respondentów). Grupę uczniów przeciętnych (uzyskujących średnią ocen między 3,01 a 4,00) tworzyło blisko 30,00\% respondentów. Uczniowie słabi i bardzo słabi (1,00-3,00) stanowili blisko 10,00\% badanych.

Uczniowie z relacjonowanej próby badawczej stanowili grupę bardzo zróżnicowaną pod kątem samooceny swojej aktywności (edukacyjno-hobbystycznej) w pozaszkolnym i pozalekcyjnym wymiarze. Najliczniejszą grupę wśród uczniów podstawówek stanowili uczniowie, którzy deklarują duże zaangażowanie w zajęcia dodatkowe, realizowane jednak poza szkołą - blisko co trzeci badany. Uczniowie określający swoje zaangażowanie jako bardzo wysokie (szkolne i pozaszkolne); wysokie (realizowane w murach szkolnych) i średnie wyrażone twierdzeniem iż aktywność taka ma miejsce „od czasu do czasu” (w formie szkolnej i pozaszkolnej) stanowili grupy mniej więcej równoliczne po około 15,00\%-20,00\% respondentów. Co dziesiąty badany określił swoje zaangażowanie w omawiany obszar jako małe, stwierdzając, iż rzadko uczestniczy w jakichkolwiek zajęciach dodatkowych. Podobna grupa uczniów nie uczestniczy w żadnych zajęciach realizowanych poza standardową, regulowaną programem nauczania, szkolną ofertą.

Syntezując i stosując spore uogólnienia, zaznaczyć należy, iż uczniowie szkół podstawowych, stanowiący próbę badawczą omawianego projektu, zamierzają kontynuować naukę w szkole ponadpodstawowej, a na myśl o przyszłości towarzyszy im zazwyczaj ciekawość oraz radość. Większość badanych wie, w jakim rodzaju szkoły chce podjąć dalszą edukację, wskazując najczęściej na liceum ogólnokształcące lub technikum. Szkoły branżowe I stopnia nie cieszą się znaczą- 
cym zainteresowaniem, tak jak nie cieszyły się zainteresowaniem przed reformą. Niegdysiejsi gimnazjaliści, podobnie jak dzisiejsi uczniowie podstawówek, nie byli zainteresowani kształceniem w szkołach zawodowych (Kozielska, 2018). Co zadziwiające, zdecydowana większość uczniów nie potrafi sformułować lub nie ma żadnych oczekiwań dotyczących wybranej przez siebie szkoły. Młodzi dokonujący wyboru szkoły ponadpodstawowej twierdzą, iż znają lokalną ofertę edukacyjną, choć istotne w tym obszarze jest to, że blisko połowa deklaruje, że mimo iż posiada wiedzę we wskazanym obszarze, to dodatkowe wsparcie informacyjne byłoby przydatne. Co sugerować może, iż podjęli decyzję „w ciemno”, gdyż ich wiedza i poziom rozpoznania sytuacji lokalnego rynku edukacyjnego, stanowiącego o „wachlarzu możliwości do wyboru”, jest niewystarczająca/niepełna. Warto zaznaczyć także, że aż co trzeci uczeń, który określał, iż wybrał już dla siebie kolejną szkołę, stwierdził jednocześnie, iż wiedzy na temat oferty: rodzajów i specjalizacji lokalnych i regionalnych szkół ponadpodstawowych nie ma w ogóle.

\section{REZULTATY}

Czerpiąc inspiracje z badań C. Timoszyk-Tomczak (2003), która analizując strategie i style konstruowania przyszłości zwracała uwagę na ich różnorodność, będącą konsekwencją miedzy innymi kontekstu, w którym żyje „konstruktor”, mnogości jego doświadczeń i wachlarza możliwości do wyboru, postanowiono zbadać deklaracje młodzieży szkół podstawowych w kwestii obieranych przez nią strategii planowania. Uczniów poproszono o wybranie dwóch deskrypcji, najlepiej eksplikujących ich aktualną sytuację, zakładając, iż młodzież może korzystać z kilku strategii jednocześnie, tworząc ich hybrydy wobec różnorodnych kontekstów młodzieńczego funkcjonowania i rozważanych obszarów.

Opowiedzenie się przez uczniów za którymś z wariantów dostarczyło informacji o preferowanym przez nich stylu działania w zakresie projektowania przyszłości i podejmowania znaczących życiowo decyzji, uwzględniając także ich temporyzacyjny aspekt. Uczniowie wybierali spośród następujących możliwości:

a) „obserwuje siebie i innych, znam siebie swoje atuty i słabe strony, wiem co dla mnie dobre, co mogę osiągnąć, na co mnie stać, bo znam warunki jakie mam (także te w swoim otoczeniu) (np.: wsparcie rodzinne, zasoby finansowe itp). Biorąc pod uwagę wcześniejsze decyzje, można powiedzieć, iż były słuszne. Nie podejmuję decyzji pochopnie, rozważam możliwości i ich konsekwencje. Potrafię je także modyfikować w zależności od sytuacji”, będącą uproszczoną eksplikacją 
strategii realistycznej - polegającej, jak wskazuje Timoszyk-Tomczak, na obserwacji innych ludzi i samego siebie w celu efektywnego działania we własnym środowisku w różnych dziedzinach życia. Wiąże się z nią umiejętność spostrzegania aktualnej rzeczywistości oraz tworzenie adekwatnych modeli przyszłego świata; wymaga rozważenia własnych pomysłów i alternatyw generowanych przez środowisko;

b) „słucham rad bardziej doświadczonych, osób starszych, wiem, że chcą dla mnie dobrze, wolę opierać się na ich zadaniu - jestem w stanie brać pod uwagę opinie innych, choć sam też chyba wiem, co dla mnie dobre”, będąca skróconą deskrypcją strategii autorytetu - uwzględniającej korzystanie z rad i wskazówek osób, które podmiot planujący, uznaje za bardziej doświadczone i kompetentne. Preferujący tę strategię, jak zaznacza autorka koncepcji, mają skłonność do kierowania się poradami osób znaczących, nie dążąc do autonomii w procesie podejmowania decyzji i kształtowania swojej przyszłości;

c) „zupełnie nie umiem sam zadecydować, mam obawy, wolę zdać się na innych posłuchać rodziców, kolegów, albo wybrać to, co i oni uznali za słuszne, tak jest bezpieczniej, lepiej się tak czuję, nie ma wtedy też kłótni, konfliktów”, będącą krótkim opisem osiowych cech strategii przymusu, prowadzącej do uzależnienia się od rodziców, nauczycieli czy np. doradców zawodowych lub innych czynników zewnętrznych. Osoby stosujące tę strategię kierują się głównie standardami narzuconymi z zewnątrz, co daje im poczucie zwolnienia z odpowiedzialności za podejmowane decyzje;

d) ,jestem marzycielem, roztaczam swoje wizje, często wskakuję na głęboką wodę, licząc, że się uda, raz wychodzi, innym razem nie, lubię sobie pofantazjować, chciałbym żeby wszystko się układało po mojej myśli, grunt to być optymistą. Często słyszę, ze coś nie jest dla mnie, że nie na moje siły, nie mój poziom, ale próbuję i wybieram taką drogę, mając nadzieję, że się uda. Jakoś specjalnie jej nie planuję, nie zastanawiam się nad konsekwencjami”, co stanowi egzemplifikację strategii życzeniowej, która bazuje na fantazjowaniu na temat własnej przyszłości, lecz bez planowania i określania sposobów realizacji zamierzeń, co znacznie ogranicza szanse na osiągnięcie celu;

e) „nie planuję, nie myślę, zdaję się na los, Boga, w sumie co ma być, to i tak będzie i nie za bardzo mam na to jakikolwiek wpływ, wszystko jest już gdzieś tam zapisane - w gwiazdach, naszym przeznaczeniu. Jestem przekonany/a, że losu nie zmienię”, będącą opisem strategii oczekiwania, opierającej się na biernym oczekiwaniu na wydarzenia życiowe. Jednostka nie formułuje celów życiowych ani sposobów ich realizacji, gdyż uznaje, że przyszłe wydarzenia zależą od pozaosobowych sił związanych z wyznawaną filozofią, ideologią czy religią. 
Taka jednostka ma poczucie, iż nie ma wpływu na swoje życie, a siłę napędową i sprawczą stanowią czynniki zewnętrzne. Taka strategia konstruowania własnej przyszłości to strategia oczekiwania;

f) „żyję wg zasady: nie planuję - żyję dniem codziennym, moje motto to: korzystaj z życia, czerp z niego pełnymi garściami, baw się - o problemach pomyślisz jutro, a poza tym kto nie ryzykuje, ten nie pije szampana”, będąca uproszczoną deskrypcją strategii carpe diem. Osoby stosujące tę strategię, jak zaznacza autorka, czerpią przyjemność z dnia codziennego, nie planując przyszłości, nie zastanawiają się nad nią. U nastolatków dążenie do wartości hedonistycznych nie oznacza jednak braku planowania przyszłości, lecz może być skutkiem życia według norm i wskazówek narzuconych z zewnątrz i braku posiadania alternatywy w momencie wyczerpania się źródeł planów. Do zahamowania procesu konstruowania przyszłości może dojść również w sytuacji przeciążenia informacjami lub dużego oporu przed zmianą, wywołanego np. poglądami, konserwatyzmem, utratą przywilejów (Timoszyk-Tomczak, 2003).

Respondenci określili, iż najlepiej opisującą ich aktualny sposób działania jest strategia realistyczna (59,50\%) oraz strategia autorytetu (46,40\%). Biorąc po uwagę kolejne wskazania, ponad 15,00\% uznało, iż ich aktualne poczynania, w kontekście przyszłości i namysłu nad nią, najlepiej opisuje strategia fantazjowania (16,40\%). Częściej niż co dziesiaty uczeń stwierdził, iż najbliższa jest mu strategia przymusu (12,00\%). Co dziesiąty (9,10\%) określił, iż jego postępowanie najbardziej wpisuje się w założenia strategii carpe diem, a 7,10\% badanych zdaje się w kwestii swojej przyszłości na czynniki zewnętrzne - takie jak los czy opatrzność. C. Timoszyk-Tomczak (2003) podkreśla, że najkorzystniejszą strategią jest poszukiwanie i wykorzystywanie działań odpowiednich dla sytuacji, w jakiej funkcjonuje i rozwija się jednostka.

Respondenci deklarujący, iż najlepiej ich działania opisuje strategia realistyczna, najczęściej jako drugą opisującą ich styl funkcjonowania w omawianym wymiarze wskazywali strategię autorytetu (41,13\%). Stanowili oni grupę mniej więcej równoliczną, biorąc pod uwagę płeć (51,68\%K i 48,32\%M). Wśród „realistów” najliczniejszą grupę stanowili uczniowie klas VII (blisko 38,00\%), dalej szóstoklasiści (32,00\%) na końcu znaleźli się uczniowie ostatniej kasy (30\%). Proporcje te uległy nieznacznym wahnięciom - uczniowie ostatnich klas zdają się tracić przekonanie co do pełni swoich możliwości w aspekcie wyboru kolejnego szczebla kształcenia. Respondenci „realiści” obierali najczęściej orientację długo - $(45,11 \%)$ lub krótkoterminową $(46,64 \%)$. Ponad połowa stosujących tę strategię (blisko 60,00\%) określiła, iż wie, w którym typie szkoły podejmie dalsze kształcenie. Grupę strategów „realistów” tworzyła najliczniej reprezentowana 
Tabela 1. Charakterystyka respondentów a wybrana strategia

\begin{tabular}{|c|c|}
\hline Strategia & Uproszczona charakterystyka grupy respondentów \\
\hline Realistyczna & $\begin{array}{l}\text { - Orientacja długoterminowa i krótkoterminowa } \\
\text { - Uczniowie z bardzo dobrymi wynikami w nauce } \\
\text { - Ponad } 90 \% \text { wybrało zawód } \\
\text { - Wysoka samoocena szans na osiągnięcie zawodowego sukcesu } \\
\text { - (p=0,0425) Najczęściej wskazywali ją uczniowie, którzy zamierzali uczyć się } \\
\text { w liceum ogólnokształcącym oraz technikum (test Fp porównujący k częstości) }\end{array}$ \\
\hline Autorytetu & $\begin{array}{l}\text { - Orientacja krótkoterminowa } \\
\text { - Uczniowie z bardzo dobrymi wynikami w nauce } \\
\text { - Blisko } 80 \% \text { wybrało zawód } \\
\text { - Samoocena szans na osiągnięcie zawodowego sukcesu określona jako wysoka } \\
\text { i wyższa niż przeciętna } \\
\text { - (p=0,0346) Najczęściej wskazywana przez uczniów, którzy zamierzali } \\
\text { kształcić się w liceum ogólnokształcącego oraz szkole branżowej (test Fp } \\
\text { porównujący k częstości) }\end{array}$ \\
\hline Przymusu & $\begin{array}{l}\text { - Orientacja krótkoterminowa } \\
\text { - Uczniowie z dobrymi wynikami w nauce } \\
\text { - } 45 \% \text { wybrało zawód } \\
\text { - Samoocena szans na osiągnięcie zawodowego sukcesu określona jako } \\
\text { przeciętna } \\
\text { - (p=0,0015) najczęściej wskazywali ją uczniowie, którzy zamierzali pójść do } \\
\text { szkoły branżowej oraz uczniowie, którzy nie wiedzieli, którą szkołę wybrać } \\
\text { (test Fp porównujący k częstości) }\end{array}$ \\
\hline Życzeniowa & $\begin{array}{l}\text { - Orientacja krótkoterminowa } \\
\text { - Uczniowie z dobrymi i bardzo dobrymi wynikami w nauce } \\
\text { - Ok. } 75 \% \text { wybrało już szkołę - LO } \\
\text { - Blisko } 70 \% \text { wybrało zawód } \\
\text { - Wysoka samoocena szans na osiągnięcie zawodowego sukcesu } \\
\text { - (p=0,5519) stosowana z podobną częstością przez uczniów aspirujących do } \\
\text { różnych typów szkół (test Fp porównujący k częstości) }\end{array}$ \\
\hline Oczekiwania & $\begin{array}{l}\text { - Orientacja krótkoterminowa i na „tu i teraz” } \\
\text { - Uczniowie z dobrymi i przeciętnymi wynikami w nauce } \\
\text { - Ponad 50\% wybrało zawód } \\
\text { - Samoocena szans na osiągnięcie zawodowego sukcesu określona jako } \\
\text { przeciętna } \\
\text { - (p=0,0178) najczęściej wskazywali ją uczniowie, którzy nie wiedzieli, do jakiej } \\
\text { szkoły pójdą (test Fp porównujący k częstości) }\end{array}$ \\
\hline Carpe diem & $\begin{array}{l}\text { - Orientacja krótkoterminowa i na „tu i teraz” } \\
\text { - Uczniowie z dobrymi i słabymi wynikami w nauce } \\
\text { - } 60 \% \text { wybrało zawód } \\
\text { - Wysoka oraz przeciętna samoocena szans na osiągnięcie zawodowego sukcesu } \\
\text { • (p=0,2556) stosowana równie często przez wszystkich uczniów (test Fp } \\
\text { porównujący k częstości) }\end{array}$ \\
\hline
\end{tabular}

Źródło: badania własne. 
grupa uczniów aspirujących do liceów ogólnokształcących (34,40\%) i techników (33,60\%). Ponadto tylko niespełna co dziesiąty z nich określał, iż nie wybrał jeszcze profesji, którą chciałby się zająć, zatem zdecydowana większość opowiadających się za omawianą strategią określiła (lub określiła z pewną dozą niepewności) swoje zawodowe preferencje, a ponad $60,00 \%$ z nich potrafiło podać nazwę, zawodu, którym jest zainteresowana. Aspiracje edukacyjne i zawodowe tej grupy wiążą się ze zdaniem matury i kontynuowaniem nauki na uczelni wyższej $(50,31 \%)$, osiągnięciem poziomu eksperckiego w wybranej przez siebie branży i zyskaniem niezależności finansowej (56,57\%). Swoje szanse na osiągnięcie sukcesu oceniają najczęściej, jako wysokie (38,23\%) lub wyższe niż przeciętne (28,29\%).

Deklarujący stosowanie strategii autorytetu najczęściej, jako drugą opisującą ich styl funkcjonowania w omawianym wymiarze wskazywali strategię realistyczną (52,75\%). Stanowili oni grupę mniej więcej równoliczną, biorąc pod uwagę płeć (51,98\%K i 48,04\%M). Wśród „potrzebujących wsparcia autorytetu” najliczniejszą grupę stanowili uczniowie klas VII (39,02\%), dalej ósmoklasiści (prawie 32,00\%) na końcu znaleźli się uczniowie klasy VI kasy (niespełna 30,00\%). Zatem czujący już zapewne nieuchronność dotyczącą podjęcia decyzji, związanej ze zbliżającym się etapem końca szkoły podstawowej, częściej wskazywali, iż w aspekcie wyboru kolejnego etapu kształcenia posiłkują się opiniami zewnętrznymi. Uczniowie ci obierali najczęściej orientację krótkoterminową (blisko 71,00\%), wskazując, iż antycypowanie przyszłości dotyczy zaledwie kolejnego etapu edukacyjnego. Do grona stosujących tę strategie należeli w zdecydowanej większości przypadków uczniowie osiągający wysokie wyniki szkolne (w przedziale 4,51-5,00) (ponad 28,00\%). Ponad połowa opowiadających się za stosowaniem tej metody konstruowania przyszłości (blisko 60,00\%) określiła, iż wie, w którym typie szkoły podejmie dalsze kształcenie. Grupę strategów „wymagających wsparcia” tworzyli najczęściej uczniowie aspirujący do liceów ogólnokształcących (blisko 36,00\%). Zdecydowana większość opowiadających się za wybraną strategią określiła (blisko 32,00\%) (lub określiła acz nie jest pewna poczynionego wyboru (blisko 46,00\%)), iż wybrała już zawód, których zamierza wykonywać. Podobnie jak „realiści” zdecydowana większość respondentów w tej grupie potrafiła określić zawód, który wybrała - podając jego nazwę. Aspiracje edukacyjne i zawodowe tej grupy wiążą się ze zdaniem matury i kontynuowaniem nauki na uczelni wyższej (50,20\%), zakończyć naukę zdaniem matury planuje co piąty respondent stosujący omawianą strategię, a blisko15,00\% chciałoby zdobyć zawód (bez matury). Aspiracje zawodowe tej grupy oscylują wokół zyskania niezależności finansowej (61,37\%), osiągnięcia poziomu eksperckiego w wybranej przez siebie branży $(57,06 \%)$ i pracy w stabilnym, bezpiecznym środowisku pracowniczym (47,06\%). Swoje 
szanse na osiągnięcie sukcesu oceniają najczęściej jako wysokie $(36,27 \%)$ lub wyższe niż przeciętne (31,76\%).

Deklarujący stosowanie strategii przymusu najczęściej jako drugą opisującą ich styl funkcjonowania w omawianym wymiarze wskazywali strategię autorytetu (28,03\%). W przeciwieństwie do zwolenników dwóch wyżej przedstawionych strategii tworzących mniej więcej równoliczne, biorąc pod uwagę płeć, grupy, opowiadających się za strategią przymusu było ponad 13,00\% więcej uczniów niż uczennic. Podobnie jak wśród „potrzebujących wsparcia autorytetu” najliczniejszą grupę stanowili w tym przypadku uczniowie klas VII (40,15\%), dalej ósmoklasiści (prawie 34,09\%), na końcu znaleźli się uczniowie VI kasy (niespełna ponad 25,00\%). Ci respondenci, podobnie jak ich koledzy wskazujący, iż ich sposób działania najlepiej obrazuje strategia autorytetu, deklarowali w największym procencie obranie krótkoterminowej orientacji (blisko 60,00\%). Do grona stosujących tę strategię należeli w zdecydowanej większości przypadków uczniowie osiągający dobre wyniki w nauce, co trzeci uzyskał średnią ocen w przedziale 4,01-4,50, a co drugi nieco niższą (3,51-4,0). Zdecydowanie mniej (tylko co trzeci), względem wskazań w poprzednich grupach różnicowanych obieraną strategią, uczniów wie, w jakim typie szkoły podejmie dalsze kształcenie. Grupę strategów „podporządkowujących swe decyzje sugestiom innych” tworzyli najczęściej uczniowie aspirujący do techników (blisko 31,06\%), a dodać warto, iż co czwarty uczeń określający, iż stosuje relacjonowaną strategię, nie wybrał jeszcze zawodu, a blisko połowa podjęła decyzję, acz nie jest przekonana o jej zasadności. Podobnie jak „,realiści” i „wymagający wsparcia”, większość respondentów w tej grupie potrafiła określić zawód, podając jego nazwę; warto dodać, iż ich udział procentowy spadł w tej grupie do 45,00\%. Aspiracje edukacyjne i zawodowe tej grupy wiążą się ze zdaniem matury i kontynuowaniem nauki na uczelni wyższej, choć odsetek wskazań względem poprzedniej grupy spada tu o blisko 15,00\% (z 50,20\% do 35,61\%) lub zakończeniem nauki na zdaniu matury (25,76\%) (co z kolei stanowi wzrost o ok. 15,00\% względem aspiracji deklarowanych przez obierających strategię autorytetu). Aspiracje zawodowe tej grupy oscylują, podobnie jak w powyższych przypadkach, wokół zyskania niezależności finansowej (57,358\%) i pracy w stabilnym, bezpiecznym środowisku pracowniczym (48,18\%), często wskazywane przez poprzednie grupy - osiągnięcie poziomu eksperckiego w wybranej przez siebie branży jest tu rzadziej wskazywane w kontekście zawodowych aspiracji (dotyczy co trzeciego ucznia). Swoje szanse na osiągnięcie sukcesu zawodowego uczniowie ci w zdecydowanej większości przypadków określają jako przeciętne (37,88\%), tylko niewiele ponad 6,00\% badanych określa je jako bardzo wysokie (dla porównania w grupie „realistów” i „wspierających się” wartość tego wskazania jest ponad dwa razy wyższa). 
Deklarujący stosowanie strategii życzeniowej najczęściej jako drugą opisującą ich styl funkcjonowania w omawianym wymiarze wskazywali strategię realistyczną (38,89\%). Widać, iż strategii opartej na fantazjowaniu towarzyszy opieranie się na samowiedzy i wspieranie się bardziej doświadczonymi innymi. Najbardziej skłonni do życzeniowego postrzegania przyszłości okazali się, tworzący równoliczne grupy, uczniowie młodszych klas VI i VII (po 35,56\%). Ósmoklasiści rzadziej przyznawali się do korzystania z tej strategii (38,89\%). Uczniowie, podobnie jak ich koledzy wskazujący, iż ich sposób działania najlepiej obrazuje strategia życzeniowa, deklarowali najczęściej obranie krótkoterminowej orientacji (choć następuje tu 10\% spadek z 60,00\% do 50,0\% odpowiedzi), wskazując, iż antycypowanie przyszłości dotyczy kolejnego etapu edukacyjnego. O 15,00\% uczniów więcej (porównując „marzycieli” do „zdających się na wybór innych” wie, w jakiej szkole podejmie dalsze kształcenie (stanowiąc blisko 75,00\% grupy). Największa część „marzycieli” planuje kontynuować naukę w liceum ogólnokształcącym (ponad 40,00\%). Aspiracje edukacyjne i zawodowe co drugiego respondenta z tej grupy wiążą się ze zdaniem matury i kontynuowaniem nauki na uczelni wyższej; zyskaniem niezależności finansowej i pracą w stabilnym, bezpiecznym środowisku pracowniczym (48,18\%). Swoje szanse na osiągnięcie sukcesu zawodowego uczniowie ci w zdecydowanej większości przypadków określają jako wyższe niż przeciętne (37,88\%) i wysokie (36,27\%).

Deklarujący stosowanie strategii oczekiwania najczęściej jako drugą opisującą ich styl funkcjonowania w omawianym wymiarze wskazywali strategię realistyczną (29,00\%), Zatem strategii opartej na wierze w nieuchronność losu i zdanie się na to, co przynosi, towarzyszyło jednak opieranie się na samowiedzy i wspieranie się bardziej doświadczonymi innymi (podobnie zresztą jak w przypadku powyżej opisanych stylów konstruowania przyszłości). Najbardziej skłonni do „wyczekiwania na to, co przyniesie przyszłość” okazali się tworzący równoliczne grupy uczniowie młodszych klas VII (45,00\%), a najrzadziej ósmoklasisci (26,00\%). Uczniowie, podobnie jak ich koledzy wskazujący, iż ich sposób działania najlepiej obrazuje strategia życzeniowa, przymusu i autorytetu, deklarowali w największej liczbie przypadków obieranie krótkoterminowej orientacji (14,10\%), równie często (na co nie wskazywali stosujący ww. strategie) określali, że nie myślą o przyszłości, co lokuje ich wśród obierających orientację na „tu i teraz”. W tej grupie respondentów znacznie spada udział osób, które wiedzą, w jakim typie szkoły podejmą edukację (stanowiąc tylko 25,00\% grupy). Największa część „oczekujących na to, co przyniesie los” planuje kontynuować naukę w technikum (40,00\%). Podobnie jak „realiści”, „wymagający wsparcia” i „zdający się na innych”, większość respondentów w tej grupie potrafiło określić zawód, podając 
jego nazwę (zdecydowanych i „chyba zdecydowanych” było 56,00\%), ale podobnie też jak w poprzednich grupach uczniowie deklarujący, iż (chyba) już wybrali zawód, nie potrafili określić kompetencji, kwalifikacji, wokół których oscyluje (blisko 53,00\%), a blisko 70,00\% dokonało wyboru profesji bez znajomości sytuacji na rynku pracy, tyle samo nie potrafiło określić swoich zainteresowań. Aspiracje edukacyjne i zawodowe co trzeciego respondenta wiązały się ze zdaniem matury i kontynuowaniem nauki na uczelni wyższej - zyskaniem niezależności finansowej i pracą w stabilnym, bezpiecznym środowisku pracowniczym (łącznie blisko 80,00\%), co piąty stawia na pracę w dużej firmie/korporacji. Swoje szanse na osiągnięcie sukcesu zawodowego uczniowie ci w zdecydowanej większości przypadków określają jako przeciętne (30,88\%), a zatem niżej niż ich koledzy wybierający inne strategie. Na myśl o przyszłości towarzyszy im, podobnie jak w przypadku ich kolegów stosujących wcześniej wymienione strategie, ciekawość, przypływ energii (15,00\%), respondenci w przeciwieństwie natomiast do swoich kolegów wymieniali także często (15,00\%), że nie czują nic oraz że odczuwają lęk, obawy i podenerwowanie (prawie 13,00\%).

Deklarujący stosowanie strategii carpe diem najczęściej jako drugą opisującą ich styl funkcjonowania w omawianym wymiarze wskazywali strategię realistyczną (35,00\%), która w każdym przypadku była najczęściej towarzyszącą, gdy wybierający nie stosował jej jako strategii podstawowej. Podobnie jak w przypadku innych, wybierających mniej efektywne strategie konstruowania przyszłości, także i tej towarzyszyło korzystanie z samowiedzy i wiedzy o otoczeniu oraz poleganie na opinii bardziej doświadczonych osób. Najbardziej skłonni do „,̇ycia dniem dzisiejszym i korzystaniem z niego” okazali się uczniowie młodszych klas VI (40,00\%), mający zapewne przekonanie, iż na poważne decyzje przyjdzie jeszcze czas, a najrzadziej siódmo- i ósmoklasiści (po 30,00\%), których przejście na kolejny szczebel edukacji stanowi mniej odległą perspektywę. Uczniowie, podobnie jak ich koledzy wskazujący, iż ich sposób działania najlepiej obrazuje strategia życzeniowa, przymusu, autorytetu i oczekiwania, deklarowali w większości przypadków obranie krótkoterminowej orientacji (43,00\%) lub (na co nie wskazywali jedynie stosujący strategię oczekiwania) określali, że nie myślą o przyszłości, co lokuje ich wśród obierających orientację na „tu i teraz” (42,00\%). W odniesieniu do uzyskiwanych wyników w nauce była najbardziej dychotomiczna. Do grona stosujących strategię carpe diem należeli w większości przypadków uczniowie osiągający bardzo dobre i dobre wyniki w nauce 4,01-5,00 (blisko 50,00\%) oraz niskie przeciętne średnie ocen 2,51-3,50 (50,00\%). W tej grupie respondentów tylko co trzeci uczeń wie, w jakim typie szkoły podejmie dalszą edukację, najchętniej wybierając liceum (30,00\%) i technikum (30,00\%). Aspiracje edukacyjne 
i zawodowe co drugiego respondenta z tej grupy wiążą się ze zdaniem matury i kontynuowaniem nauki na uczelni wyższej (zatem są wyższe niż u stosujących strategię oczekiwania), zyskaniem niezależności finansowej (65,00\%). Swoje szanse na osiągnięcie sukcesu zawodowego uczniowie ci określają w szerokim dość spektrum od bardzo wysokich (20,00\%) przez wysokie (20,00\%) do przeciętnych (20,00\%). Na myśl o przyszłości towarzyszy im podobnie jak w przypadku ich kolegów stosujących wcześniej wymienione strategie ciekawość, przypływ energii (20,00\%), deklarują także, iż odczuwają swoistą ambiwalencję od radości po lęk $(20,00 \%)$.

\section{PODSUMOWANIE}

Istotnym zagadnieniem w podjętej narracji jest kwestia deklaracji dotyczącej przyjmowanej strategii namysłu nad przyszłością, a w jej rezultacie dokonania wyboru dotyczącego zawodu i szkoły (której ukończenie umożliwi jego wykonywanie), a dalej miejsca pracy. Wybór ten jawi się jako życiowo doniosła decyzja (Myszka-Strychalska, 2015) z uwagi na konsekwencje, które przynosi. Od trafności wyboru zawodowego kształtu biografii zależy nie tylko satysfakcja z przyszłej pracy zawodowej, ale również pozycja, jaką jednostka może zająć w społeczeństwie, a co za tym idzie - powodzenie w życiu pozazawodowym (Wołk, 2006; Wiatrowski, 2005). Decyzja chybiona skutkuje niepożądanymi konsekwencjami ekonomicznymi (koszty edukacji i przekwalifikowania) i emocjonalnymi (frustracja, niezadowolenie, brak pewności siebie i zaniżone poczucie własnej wartości) (Kukla, 2006; Karmolińska-Jagodzik, 2009).

Wybór zawodu (uwzględniając jego procesualny charakter: przygotowanie, podjęcie decyzji, realizacja zamierzeń/ewaluacja - korekta (Smykowski, 2000)) jest ważnym procesem w życiu jednostki, realizowanym wobec przyjmowanej strategii, na kanwie podejmowanych decyzji edukacyjno-zawodowych, wpływając na ukierunkowanie rozwoju kariery. Jego urzeczywistnienie wymaga namysłu nad przyszłością, popartego refleksją dotyczącą jej antycypowanego kształtu, czyli wcześniejszego wykreowania wizji przyszłości zawodowej przez jednostkę, podyktowanej przyjęciem określonego ukierunkowania zawodowego, zgodnego z celami życiowymi i aspiracjami podmiotu oraz uznanymi przez niego wartościami. Spełnienie tego zadania zmusza człowieka do namysłu nad sobą (stymuluje do pogłębionych rozważań nad własnymi możliwościami, predyspozycjami oraz oczekiwaniami) i światem (kontekstem zewnętrznych uwarunkowań). Wymaga opanowania odpowiedniej wiedzy na temat świata i swojego w nim (obecnego 
i antycypowanego) miejsca, aktualnej sytuacji na rynku pracy, puli zawodów do wyboru (z uwzględnieniem tych określanym mianem zawodów przyszłości) oraz tendencji społeczno-gospodarczych kraju czy choćby lokalnych uwarunkowań rynkowych. Zadanie związane $\mathrm{z}$ dokonywaniem przemyślanych decyzji edukacyjno-zawodowych okazuje się szczególnie trudne zwłaszcza dla młodzieży, która zdecydowanie częściej koncentruje się na wyborze szkoły (o której myśli w zasadzie w przededniu ukończenia aktualnego szczebla kształcenia) niż na konstruowanym perspektywicznie rozwoju zawodowym (Kukla, 2006). Co wiąże się z tym, że partycypująca w rzeczywistości zorientowanej na „tu i teraz” młodzież, której kontekst stanowi unowocześniona natychmiastowość z całym wachlarzem rozmaitych opcji do wyboru (niczym w supermarkecie), nie dając przy tym wskazówek, nie stawiając drogowskazów i pewników, jest w tej rzeczywistości zagubiona (Wojtasik, 1997, 2003; Melosik, 2004; Piorunek, 2004; Tomaszewska-Lipiec, 2008a, b).

Działania zaplanowane, niezależnie od tego, czego dotyczą, sprzyjają osiąganiu zamierzonych efektów częściej niż działania realizowane spontaniczne, nieprzemyślane oraz chaotyczne. Podobnie jest w przypadku zawodowej biografii. Zaplanowanie poszczególnych jej elementów i etapów, a w konsekwencji działań związanych z ich realizacją, nadaje pewien porządek i kierunek temu, co człowiek chce robić w sferze zawodowej. Świadoma swej sprawczości jednostka, która planuje działania, ma poczucie, że to, co ją spotyka, zależy od niej samej, że ma wpływ na wiele rzeczy i sytuacji, stanowiących kontekst jej zawodowych zmagań. Oczywisty pozostaje fakt, iż człowiek egzystujący aktualnie w trudnych do przewidzenia warunkach nie może przyszłości przewidzieć i w związku z tym realizować długoterminowych planów, licząc na ich stuprocentowe powodzenie. Niespodziewane i nieplanowane zdarzenia są częścią biografii, stąd też nie należy odrzucać planowania kariery, ale traktować plany jako coś otwartego, elastycznego poddającego się modyfikacjom (Krause, 2010; Plewka, 2016).

(Młody) człowiek staje się obecnie aktywnym konstruktorem własnej tożsamości i biografii (w tym jej zawodowej odsłony), kreśląc scenariusz życia - by nie „przegrać życia” (Krzychała, 2007, s. 9) powinien planować przyszłość oraz optymalnie wykorzystywać potencjał, zasoby społeczno-osobiste oraz mieć rozeznanie własnych ograniczeń oraz oferty edukacyjnej (z której może skorzystać) i sytuacji na rynku pracy (w kontekście której dokonuje edukacyjno-zawodowych wyborów). Obecny kształt rynku pracy wymaga od jednostki dużej elastyczności, ponieważ, na co zwraca uwagę A. Bańka (2006), funkcjonowanie na tym rynku wymusza od pracowników nie tylko gotowość do zmiany stanowiska czy miejsca pracy, ale i przechodzenia od stanu bezrobocia do pracy i odwrotnie. 
Konkludując powyższe rozważania, zaznaczyć warto, iż projektowanie, planowanie jest rodzajem działalności dającej szansę rozwoju adolescenta - wobec założenia, że plany życiowe stanowią refleksyjną treść zorganizowanej trajektorii tożsamości, a planowanie życia to sposób, w jaki jednostka czyni w kategorii ciągłości swojej biografii, przebieg przyszłych działań, wyrażając celowo-racjonalne zamiary i oczekiwania względem przyszłości (Krzychała, 2007). To, ku jakiej strategii konstruowania przyszłości skłaniać się będą w swoich przedsięwzięciach podejmowanych na rzecz kariery - może stanowić wyznacznik poczucia ich zawodowej satysfakcji oraz poczucia osiągnięcia sukcesu zawodowego versus jego braku.

\section{Bibliografia}

Bańka, A. (2006). Psychologiczne doradztwo karier. Poznań: Wydawca Stowarzyszenie Psychologia i Architektura Poznań.

Hampton, K.N., Sessions, L.F., Her, E.J., Rainie, L. (2009). Social Isolation and New Technology. Pew Internet \& American Life Project: Washington. Pobrane z: https://www. pewresearch.org/internet/Reports/2009/18-Social-Isolation-and-New-Technology.aspx. Karmolińska-Jagodzik, E. (2009). Młodzież ze środowisk zagrożonych marginalizacjq wobec własnej przyszłości, Poznań-Leszno: Współwydawcy: Wyższa Szkoła Humanistyczna im. Stanisława Leszczyńskiego w Lesznie, Drukarnia HAF w Lesznie.

Kozielska, J. (2018a). Wybory edukacyjno-zawodowe uczniów gimnazjów, w tym uczniów ze specjalnymi potrzebami edukacyjnymi w kontekście kondycji doradztwa zawodowego. Interdyscyplinarne Konteksty Pedagogiki Specjalnej, 20.

Kozielska, J. (2018b). Wybory edukacyjno-zawodowe młodzieży gimnazjalnej w kontekście aktualnych potrzeb rynku pracy. Rocznik Lubuski, 44.

Krause, E. (2010). Znaczenie procesu planowania kariery zawodowej w „wieku studiów”. Szkoła - Zawód - Praca, 1 (17).

Krzychała, S. (2007). Projekt życia. Młodzież w perspektywie badań rekonstrukcyjnych. Wrocław: Wydawnictwo Naukowe Dolnośląskiej Szkoły Wyższej Edukacji TWP.

Kukla, D. (2006). Perspektywy (nie tylko zawodowe) młodych w ponowoczesności. W: S.M. Kwiatkowski, Z. Sirojć (red.), Młodzież na rynku pracy. Od badań do praktyki. Warszawa: Ochotnicze Hufce Pracy Komenda Główna.

Liberska, H. (2004). Perspektywy temporalne młodzieży. Wybrane uwarunkowania. Poznań: Wydawnictwo Naukowe UAM.

Melosik, Z. (2004). Kultura popularna jako czynnik socjalizacji. W: Z. Kwieciński, B. Śliwerski (red.), Pedagogika II. Podręcznik akademicki. Warszawa: Wydawnictwo Naukowe PWN.

Myszka-Strychalska, L. (2015). Planowanie i zarządzanie karierą jako podmiotowa „własność” jednostki. Ogrody Nauk i Sztuk, 5.

Piorunek, M. (2004). Projektowanie przyszłości edukacyjno-zawodowej w okresie adolescencji. Poznań: Wydawnictwo Naukowe UAM. 
Plewka, Cz. (2016). Aspiracje edukacyjno-zawodowe młodzieży gimnazjalnej. Szkic monograficzny ilustrowany relacjami własnych badań empirycznych. Koszalin: Wydawnictwo Politechniki Koszalińskiej.

Robinson, J. (2000). What Are Employability Skills? The Workplace, Vol. 1, Issue 3.

Smykowski, B. (2000). Podejście rozwojowe do badania form zachowań. W: A. Brzezińska (red.), Wygotski i z Wygotskim w tle. Toruń: Wydawnictwo UMK.

Timoszyk-Tomczak, C. (2003). Strategie konstruowania własnej przyszłości. Szczecin: Wydawnictwo Naukowe Uniwersytetu Szczecińskiego.

Tomaszewska-Lipiec, R. (2008a). Absolwent na rynku pracy - wybrane zagadnienia. W: A. Karpińska, W. Wróblewska (red.), Dylematy dydaktyki szkoły wyższej: w dialogu i perspektywie. Białystok: Wydawnictwo Trans Humana.

Tomaszewska-Lipiec, R. (2008b). Aspiracje zawodowe uczniów szkół ponadgimnazjalnych na tle potrzeb rynku pracy. W: E. Gaweł-Luty, J. Kojkoł (red.). Edukacja wobec tożsamości społecznej. Gdańsk: Wydawnictwo Harmonia.

Wiatrowski, Z. (2005). Podstawy pedagogiki pracy. Bydgoszcz: Wydawnictwo WAM.

Wojtasik, B. (1997). Warsztat doradcy zawodu. Warszawa: Wydawnictwo Naukowe PWN.

Wojtasik, B. (2003). Refleksyjne konstruowanie kariery życiowej w ponowoczesnej codzienności, Teraźniejszość - Człowiek - Edukacja, numer specjalny.

Wołk, W. (2006). Poradnictwo zawodowe w edukacji młodzieży. Zielona Góra: Oficyna Wydawnicza Uniwersytetu Zielonogórskiego. 